\title{
MICROBIOLOGICAL MONITORING OF MINERAL WATER COMMERCIALIZED IN BRAZIL
}

\author{
André Venturini Pontara, Christianne Dezuani Dias de Oliveira, Amir Horiquini Barbosa, Rafael Aparecido dos Santos, \\ Regina Helena Pires, Carlos Henrique Gomes Martins*
}

Laboratório de Pesquisa em Microbiologia Aplicada, Universidade de Franca, Franca, SP, Brasil

Submitted: March 16, 2010; Returned to authors for corrections: May 24, 2010; Approved: January 13, 2011.

\begin{abstract}
The quality of mineral water commercialized in Brazil regarding the microbial content was analyzed and the results were compared with the standards established by the current legislation. Results demonstrated there was no bacterial contamination, but several types of fungi were found. Therefore, bottled mineral water could be considered a possible route for the transmission of filamentous fungi and yeasts.
\end{abstract}

Key words: Mineral water, microbial contamination, membrane filter technique, fungi.

Ecosystems and population in general are both dependent on river water which, besides being scarce, is also being endangered by reckless industrial waste disposal and sewage spilling. Regarding natural mineral water, the type of water that is directly obtained from natural sources or artificially collected from underground aquifers are characterized by a defined and constant presence of mineral salts and microminerals, among others $(2,6)$.

Besides that, natural mineral water should present riskfree features concerning consumers' health. The processes of water collection, processing, and bottling must comply with all the sanitary regulations, and the handling processes (collection, storage, filtration, and transportation) must not alter its original composition (8).

However, the occurrence of gastrointestinal disturbances due to the consumption of this type of water has called for investigations into its microbiology (17). Researches on the ecology of mineral water have shown that samples collected directly from the water bank have a bacterial population of approximately 10-100 colony-forming units (CFU) per milliliter $(\mathrm{mL})$. After bottling, this amount is increased to approximately $10^{3}-10^{6} \mathrm{CFU} / \mathrm{mL}(4,17)$. Indeed, the samples are not sterile products. What happens is that large amounts of their bacterial content and organic material, in suspension, are lost when water flows through rocks and soil (17).

Indicator microorganisms are commonly used to evaluate the quality of a final product and the hygiene level used throughout its processing. Isolation and identification of specific pathogens are adequate for the investigation and control of outbreaks only, since their use is not practical, is time-consuming, and requires expensive techniques.

Yeasts are significant components of most natural aquatic ecosystems. Some of them may survive for longer periods, because of their ability to form biofilms (12). Most of these organisms are not pathogenic to humans. Nonetheless, a small number of species - primarily those within the genus Candida,

*Corresponding Author. Mailing address: Laboratório de Pesquisa em Microbiologia Aplicada, Universidade de Franca. Av. Dr. Armando Salles Oliveira, 201, CEP 14404-600, Franca, SP, Brasil; Tel.: 16 3711-8756; E-mail: martinsc@unifran.br 
are important opportunist pathogens (13). In fact, C. albicans is the most frequent human pathogen, and some researches have correlated its presence in aquatic environments to recent human or animal fecal contamination $(13,28)$. Other yeast genera such as Rhodotorula have been acknowledged as important emerging human pathogens (16), with high resistance to commonly prescribed antifungal agents (11).

Filamentous fungi are naturally found in soil and water and rarely become pathogenic to immunocompetent hosts. However, immunodeficient patients are widely susceptive to fungal infections and some previous works have reported the isolation of fungi in bottled water $(7,19,26,30)$.

Once standard criteria for data interpretation concern bacteria only (5), and because the reason why fungi occur in mineral water remains unknown, the aim of this paper is to verify the microbial content of mineral water sold in 20-liter bottles in Brazil. The presence of fecal coliforms and/or thermo-tolerant and total coliforms, as well as the content of both filamentous fungi and yeasts was analyzed.

To this end, three samples of five different brands of mineral water were analyzed, which amounted to a total of fifteen examined samples. All of them were commercialized by companies within the state of São Paulo and sold in the city of Franca, Brazil. The samples were collected in the same conditions as they are available to customers - in their original 20-liter bottles, sealed, and with no external contamination. After agitation, the initial content of the bottle, considered a representative amount of the sample $(100 \mathrm{~mL})$, was processed by means of the membrane filter technique (9), using cellulose acetate membrane (Millipore, Massachusettes, USA) with $0.45 \mu \mathrm{m}$ pores. After filtration, the membranes were placed onto dishes containing the following culture media: Endo-LES agar/M-FC medium (Sabouraud-dextrose Agar - SDA, Difco Laboratories, Detroit, MI, USA), used for analysis of total/fecal coliforms, or supplemented with chloramphenicol $(30 \mathrm{mg} / 100$ $\mathrm{mL}$ ) (Sigma, St. Louis, MO, USA) for determination of fungal growth. After a specific incubation period, the number of colonies was determined and expressed as the number of CFU per $100 \mathrm{~mL}$ water sample (9). Representative colonies were extracted from the colonies that presented the same morphology inside the same dish. They were then subcultivated for identification.

All yeast isolates were identified by physiological tests (germ-tube formation, biochemical characteristics including carbohydrate assimilation (API 20C AUX, Biomerieux SA, Lyon, France) and morphology (corn-meal-Tween 80 agar). Identification of filamentous fungi was accomplished by observation of macroscopic and microscopic characteristics, as previously described for each group $(21,25)$. The pure bacterial isolates were subcultured and identified by cultural and biochemical tests. The commercial systems "BBL Crystal" Gram-positive ID Kit and Enteric Nonfermenter ID Kit (Becton \& Dickinson, MD, USA) were required for the definitive identification of isolates to the species level.

No sample presented growth of typical colonies of total or fecal coliforms in Endo-LES or M-FC medium after incubation in bacteriologic oven for $24 / 48$ hours at $37^{\circ} \mathrm{C} / 45^{\circ} \mathrm{C}$, respectively. Thus, identification of bacteria was not necessary and the CFU result was expressed as $<1 / 100 \mathrm{~mL}$ water.

The amount of CFU of fungi/100 mL mineral water is shown in Table 1 for each of the analyzed brands. The average total count of fungi was $41.53 \pm 0.40 \mathrm{CFU} / 100 \mathrm{~mL}$ water, and brand $\mathrm{C}$ presented the smallest quantities.

Table 1. Minimum and maximum values of fungal counts in different brands of mineral water.

\begin{tabular}{cc}
\hline BRAND & Min-Max (CFU/100mL) \\
\hline A & $6-32$ \\
B & $10-100$ \\
C & $4-6$ \\
D & $20-100$ \\
E & $7-100$
\end{tabular}


All the analyzed samples presented growth of fungi colonies, in a total of 32 isolates. The mycobiota was dominated by filamentous fungi (22 isolates), but yeasts were also detected (10 isolates). A complete description of the isolated microorganisms is depicted in Table 2. Among the filamentous fungi, Penicillium spp. prevailed, accounting for $31.2 \%$ of the total number of isolates. Indeed, three different Penicillium species were identified (Table 2). Fusarium spp., Trichoderma spp., Acremonium spp., and Curvularia spp. were the fungi with the smallest percentage of isolation. More specifically, Fusarium spp was isolated from sample 14, Brand E; Trichoderma spp was recovered from sample 12, Brand D. Acremonium spp. and Curvularia spp. were detected in the same, namely sample 1, brand A (Table 2). Yeasts were represented by two genera: Rhodotorula (R. glutinis) and Candida (C. parapsilosis). R. glutinis comprised $21.9 \%$ of the isolates (Table 2). Considering both yeasts and filamentous fungi, Brand A presented the highest number of isolates (11).

Table 2. Distribution of 32 isolates of fungus and yeasts obtained from the 15 samples of processed mineral water.

\begin{tabular}{ccl}
\hline Brand & Sample & \\
\hline A & 1 & Acremonium spp., Penicillium brevicompactum, Candida parapsilosis, Rhodotorula glutinis, Curvularia spp. \\
A & 2 & Cladosporium cladosporioides, Penicillium brevicompactum, Rhodotorula glutinis, C. parapsilosis \\
A & 3 & Penicillium brevicompactum, Rhodotorula glutinis \\
B & 4 & Penicillium expansum \\
B & 5 & Penicillium expansum \\
B & 6 & Rhodotorula glutinis, Penicillium expansum \\
C & 7 & Penicillium expansum \\
C & 8 & Rhodotorula glutinis, C. parapsilosis, Cladosporium cladosporioides \\
C & 9 & Cladosporium cladosporioides \\
D & 10 & Cladosporium spp., Rhodotorula glutinis \\
D & 11 & Cladosporium spp., Penicillium citrinum \\
D & 12 & Trichoderma spp., Penicillium citrinum \\
E & 13 & Rhodotorula glutinis, Cladosporium spp, Aspergillus ochraceus \\
E & 14 & Fusarium spp., Aspergillus terreus \\
E & 15 & Penicillium citrinum \\
\hline
\end{tabular}

The consumption of mineral water is quite popular among certain groups of the Brazilian population. Nowadays, Brazil has the sixth largest production of mineral water in the world, with a production of approximately 3.5 billion liters in 2000 (8). The reason for this popularity partly lies on the therapeutic and medicinal properties attributed to mineral water, but the concept of purity commonly associated with it also accounts for its increased consumption (14).
The growing concern about health due to progressive water pollution has also been responsible for promoting the sale of bottled mineral water after the 80s (17). Even though it has been associated with purity due to its underground origin, it may not be true that the microbiological quality of mineral water is superior to the quality of the water available from public supplies (30).

None of the samples investigated here presented bacterial 
growth in Endo-LES or M-FC media, which confirms the absence of fecal and/or thermo-tolerant coliforms and total coliforms in the tested water samples. In accordance with the current Brazilian legislation (5) referring to standards regarding the microbiological contents of both natural and mineral water, there should be no traits of fecal or coliform bacteria. Water is not considered to be pure when it presents total and fecal coliforms, which means the water has been contaminated by an external agent of fecal and/or environmental origin. This contamination might occur in its source or during bottling (due to the process itself or lack of hygiene), transportation, or storage. The results obtained in the first part of this investigation thus demonstrate that the analyzed brands of mineral water have excellent microbiological quality after bottling.

There are few reports in the literature regarding the occurrence of yeasts and filamentous fungi in treated water and bottled mineral water. This is partly due to the fact that causal relationships between fungal occurrence and water quality remain uncertain. However, a dramatic increase in the number of invasive diseases due to fungi has occurred recently. This rise has been attributed to the large numbers of patients undergoing immunosuppressive therapies, chemotherapy, and organ and bone marrow transplants. All the samples of mineral water analyzed here presented fungal growth. This suggests that, even though these fungi are commonly found in our environment, contamination or active growth takes place in the mineral water. The two most abundant genera of filamentous fungi found in this work were Penicillium spp. (31.2\%) and Cladosporium spp. (18.7\%). In a previous research (15), a lower level of contamination was reported $(15.4 \%)$, but the same fungi were isolated, though in different percentages: Penicillium spp. (37.8\%) and Cladosporium spp. (13.3\%). Another research also reports the prevalence of the genera Penicillium sp, Cladosporium sp, and Alternaria sp as determined in the mycological analysis of mineral water (7).

Many studies lack data on the detected species, as they were seldom identified to that level. Particularly, several species belonging to the genus Penicillium were often isolated. Many of these species are commonly related to allergies, asthma, and other respiratory pathologies (27), and they also produce mycotoxins $(P$. citrinum - citrinine $(10) ; P$. expansum and $P$. brevicompactum - patuline) (24), which represents high risk to consumers.

Aspergillus spp. totalized $6.2 \%$ of the isolates. A preliminary study following the same methodology applied here has also shown that fungal growth (species of the Aspergillus genus) can occur in mineral water that has been stored at $10^{\circ} \mathrm{C}$ and $25^{\circ} \mathrm{C}$ for a few months (15). The Aspergillus genus consists of widely distributed saprobic fungi that are filamentous and produce spores commonly found in the atmosphere. Furthermore, they produce mycotoxins (aflatoxin, toxic secondary metabolites) able to cause acute or chronic infection in humans and animals, depending on the amount that is consumed. The main pathology related to this genus is invasive aspergillosis (22), which is primarily acquired through inhalation (21), but previous research has pointed water as the main source of infection by these fungi (1).

Fusarium, an important phytopathogen that causes keratitis, onychomycosis, fungemia, invasive nasal infections, pneumonia, and cutaneous infections especially in burnt patients (21), was isolated in $3.1 \%$ in this study. These species have been acknowledged as agents of localized infections in immunocompetent individuals and of non-localized infections in severely immunodeficient patients (22).

Adherence of fungi to the internal surface of plastic bottles has also been reported, which enables certain microorganisms to survive for longer periods in water (23). In our study, $30 \%$ of the yeasts isolates consisted of $C$. parapsilosis, in accordance with a previous study by Yamaguchi et al (30). Adhesion (29) and subsequent biofilm formation (18) are especially important to C. parapsilosis, since there are evidences that its ability to adhere to plastic 
surfaces (23) is responsible for triggering the infectious processes caused by this species (18).

Rhodotorula species are rarely pointed as human pathogens. However, the high activity of phospholipase enzymes in these microorganisms indicates a possible determiner of potential pathogenicity (20). In our study, $70 \%$ of yeast isolates consisted of $R$. glutinis, in agreement with a previous study (2).

It was also observed that mineral water companies set different expiration dates for their products. According to information on some bottles, water should be consumed within two months, whereas others inform expiration dates within a year. To ensure its qualities, the water must not be submitted to any industrial processes and should remain in natura, so it is crucial that it is consumed as soon as possible (17).

Water contamination previous to bottling and bottle sealing has been reported and may have been caused by previously contaminated plastic bottles (31). Bottles may have been contaminated due to deficient sterilization processes (8) or lack of hygiene during their manufacture and storage (15).

These findings indicate that the general perception that bottled water is safe and clean is not true. The risk of disease may be limited for healthy individuals, but immunocompromised patients are generally more susceptible to infection and might thus be at higher risk of being infected. In addition, these results could contribute to re-evaluation of the criteria used to analyze the microbial content of drinking water, because yeasts and filamentous fungi were detected in samples where total/fecal coliforms were not detected.

\section{REFERENCES}

1. Anaissie, E.J.; Stratton, S.L.; Diganani, M.C.; Summerbell, R.C.; Rex, J.H.; Monson, T.P.; Spencer, T.; Kasai, M.; Francesconi, A.; Walsh, T.J. (2002). Pathogenic Aspergillus species recovered from a hospital water system: a 3-year prospective study. Clin. Infect. Dis. 34, 780-789.

2. Ancasi, E.G.; Carrillo, L.; Benítez-Ahrendts, M.R. (2006) Moulds and yeasts in bottled water and soft drinks. Rev. Argent. Microbiol. 38, 93-
96.

3. Bischofberger, T.; Cha, S.K.; Schmit, R.; Konig, B.; Schmidt-Lorenz, W. (1990) The bacterial flora of non-carbonated, natural mineral water from the springs to reservoir and glass and plastic bottles. Int. J. Food Microbiol. 11, 51-72.

4. Brasil - Agência Nacional de Vigilância Sanitária (ANVISA): Regulamento técnico para fixação de identidade e qualidade de água mineral e água natural. 2000, Resolução RDC n 54 de 15/06/2000 DOU de 19/06/2000.

5. Brasil - Agência Nacional de Vigilância Sanitária (ANVISA): Regulamento técnico referente a padrões de identidade e qualidade para água mineral natural e água natural. 1999, Resolução nº 310 de 16/07/1999 - DOU de 19/07/1999.

6. Brasil - Ministério da Saúde: Estabelece os procedimentos e responsabilidades relativos ao controle e vigilância da qualidade da água para consumo humano e seu padrão de potabilidade, e dá outras providências. 2004, Portaria $\mathrm{n}^{\circ} 518$ de 25/03/2004 - DOU de 26/03/2004.

7. Cabral, D.; Fernández, P. (2002). Fungal spoilage of bottled mineral water. Int. J. Food Microbiol. 30, 73-76.

8. Cardoso, C.C.; Veiga, S.M.O.M.; Nascimento, L.C.; Fiorini, J.E.; Amaral, L.A. (2003). Avaliação microbiológica de um processo de sanificação de galões de água com a utilização do ozônio. Ciênc. Tecnol. Aliment. 23, 59-61.

9. Clesceri, L.S.; Greenberg, A.S.; Eaton, A.D. Standard Methods for the Examination of water and wastewater, 21th edition, APHA, Washington, 2005.

10. Criado, M.V.; Fernandez, P.V.E.; Badessari, A.; Cabral, D. (2005). Conditions that regulate the growth of moulds inoculated into bottled mineral water. Int. J. Food Microbiol. 99, 343-349.

11. Diekema, D.J.; Petroelzi, B.; Messer, S.A.; Hollis, R.J.; Pfaller, M.A. (2005). Activities of available and investigational antifungal agents against Rhodotorula species. J. Clin. Microbiol. 43, 476-478.

12. Doggett, M.S. (2000). Characterization of fungal biofilm within a municipal water distribution system. Appl. Environ. Microbiol. 66, 12491251.

13. Efstratiou, M.A.; Mavridou, A.; Richardson, S.C.; Papadakis, J.A. (1998). Correlation of bacterial indicator organisms with Salmonella spp., Staphylococcus aureus and Candida albicans in sea water. Lett. Appl. Microbiol. 26, 342-346.

14. Eiroa, M.N.U.; Junqueira, V.C.A.; Silveira, N.F.A. (1996). Avaliação microbiológica de linhas de captação e engarrafamento de água mineral. Ciênc. Tecnol. Aliment. 16, 165-169.

15. Fujikawa, H.; Wauke, T.; Kusunoki, J.; Noguchi, Y.; Takahashi, Y.; Ohta, K, Itoh, T. (1997). Contamination of microbial foreign bodies in 
bottled mineral water in Tokyo, Japan. J. Appl. Microbiol. 82, 287-291.

16. Hazen, K.C. (1995). New and emerging yeast pathogens. Clin. Microbiol. Rev. 8, 462-478.

17. Hunter, P.R. (1993). A review: the microbiology of bottled natural mineral waters. J. Appl. Bacteriol. 74, 345-352.

18. Kuhn, D.M.; Chandra, J.; Mukherjee, P.K.; Ghannoum, M.A. (2002). Comparison of biofilms formed by Candida albicans and Candida parapsilosis. Diagn. Microbiol. Infect. Dis. 70, 887-898.

19. Lal, M.; Kaur, H. (2006). A microbiological study of bottled mineral water marketed in Ludhiana. Indian J. Public Health 50, 31-32.

20. Mayser, P.; Laabs, S.; Heuer, K.U.; Grunder, K. (1996). Detection of extracellular phospholipase activity in Candida albicans and Rhodotorula rubra. Mycopathologia 135, 149-155.

21. McGinnis, M.R. Laboratory Handbook of Medical Mycology. Academic Press, New York, 1980.

22. Nucci, M.; Anaissie, E. (2002). Cutaneous Infection by Fusarium species in healthy and immunocompromised hosts: implications for diagnosis and management. Clin. Infect. Dis. 35, 909-920.

23. Panagoda, G.J.; Ellepola, A.N.; Samaranayake, L.P. (2001). Adhesion of Candida parapsilosis to ephitelial and acrylic surfaces correlates with cell surface hydrophobicity. Mycoses 44, 29-35.

24. Paterson, R.R.M. (2004). The isoepoxydon dehydrogenase gene of patulin biosynthesis in cultures and secondary metabolites as candidate
PCR inhibitors. Mycol. Res. 108, 1431-1437.

25. Pitt, J.I. A laboratory guide to common Penicillium species. CSIRO Food Research Laboratory, North Ryde, Australia, 1985.

26. Ribeiro, A.; Machado, A.P.; Kozakiewicz, Z.; Ryan, M.; Luke, B.; Buddie, A.G.; Venancio, A.; Lima, N.; Kelly, J. (2006). Fungi in bottled water: a case study of a production plant. Rev. Iberoam. Micol. 23, 139144.

27. Schwab, C.J.; Straus, D.C. (2004). The roles of Penicillium and Aspergillus in sick buildings syndrome. Adv. Appl. Microbiol. 55, 215237.

28. Solic, M.; Krstulovic, N.; Jozic, S.; Curac, D. (1999). The rate of concentration of faecal coliforms in shellfish under different environmental conditions. Environ. Int. 25, 991-1000.

29. Weems, J.J.Jr. (1992). Candida parapsilosis: epidemiology, pathogenicity, clinical manifestations, and antimicrobial susceptibility. Clin. Infect. Dis. 14, 756-766.

30. Yamaguchi, U.M.; Rampazzo, R.C.P.; Yamada-Ogatta, S.F.; Nakamura, C.V.; Ueda-Nakamura, T.; Dias, B.P.F. (2007). Yeasts and filamentous fungi in bottled mineral water and tap water from municipal supplies. Braz. Arch. Biol. Technol. 50, 1-9.

31. Yoshimatsu, M. (1996). Environments for mineral water production in factories. Journal of the Society of Heating, Air-Conditioning and Sanitary Engineers of Japan 70, 25-30. 